\title{
Acute Effects of Whey Protein, Alone And Mixed With Other Macronutrients, On Blood Pressure And Heart Rate In Older Men
}

\section{Avneet Oberoi}

The University of Adelaide

Caroline Giezenaar

Massey University

Kylie Lange

The University of Adelaide

Karen L Jones

The University of Adelaide

Michael Horowitz

The University of Adelaide

Ian Chapman

The University of Adelaide

Stijn Soenen ( $\nabla$ stijn.soenen@adelaide.edu.au )

Bond University

\section{Research Article}

Keywords: Aging, Diet, Whey protein, Blood pressure, Heart rate

Posted Date: January 19th, 2022

DOI: https://doi.org/10.21203/rs.3.rs-1164658/v1

License: (9) This work is licensed under a Creative Commons Attribution 4.0 International License.

Read Full License 


\section{Abstract}

Background: Caloric supplements are increasingly used by older people, aiming to increase daily protein intake. These high caloric drinks, rich in glucose and whey-protein in particular, may result in potential harmful decreases in blood pressure (BP). The effect of ingesting whey-protein with glucose and fat is unknown. It has been assumed that the maximum fall in systolic blood pressure occurs within 2 hours of a meal.

Methods: This study aimed to determine the effects of whey-protein, alone and mixed with other macronutrients, on systolic (SBP) and diastolic (DBP) blood pressure and heart rate (HR) in older men for 3 hours. Thirteen older men (age $75 \pm 2 \mathrm{yrs}$; body mass index (BMl) $25.6 \pm 0.6 \mathrm{~kg} / \mathrm{m}^{2}$ ) ingested a study drink on separate study days: (i) $70 \mathrm{~g}$ whey-protein $\left(\mathrm{P}_{280}\right)$; (ii) $14 \mathrm{~g}$ whey-protein, $28 \mathrm{~g}$ carbohydrate, $12.4 \mathrm{~g}$ fat $\left(\mathrm{M}_{280}\right)$; (iii) $70 \mathrm{~g}$ whey-protein, $28 \mathrm{~g}$ carbohydrate, $12.4 \mathrm{~g}$ fat $\left(\mathrm{M}_{504}\right)$; or (iv) a non-caloric control drink (C).

Results: SBP decreased after all three nutrient drinks compared to the $\mathrm{C}$, with the greatest reduction after the $\mathrm{M}_{504}$ drink ( $P=0.008$ ). Maximal decreases in SBP (C: $-14 \pm 2 \mathrm{mmHg}, \mathrm{P}_{280}:-22 \pm 2 \mathrm{mmHg}, \mathrm{M}_{280}$ : $-22 \pm 4 \mathrm{mmHg}, \mathrm{M}_{504}:-24 \pm 3 \mathrm{mmHg}$ ) occurred about 2 hours after drink ingestion and persisted thereafter (120-180min: $\mathrm{P}_{280}$ and $\mathrm{M}_{504}$ vs. C $\left.P<0.05\right)$. Maximum DBP decreases and HR increases occurred after $M_{504}$, with no differences between the effects of the $P_{280}$ and $M_{280}$ drinks.

Conclusions: The effects of whey-protein containing drinks to lower BP and increase HR may persist for at least 3 hours after ingestion, and appear to be dependent on their energy content rather than macronutrient composition. Pure whey-protein drinks may represent the best approach to maximize protein intake while minimizing the potential for deleterious BP falls in older people.

\section{Trial registration: ACTRN12614000846628, 14/03/2019}

\section{Introduction}

Older people are increasingly encouraged to take high protein nutritional supplements to reduce the ageassociated loss of muscle mass and function [1]. Whey protein is often part of these supplements, given that it is high in essential amino acids and appears to be effective in stimulating muscle protein formation [2].

Ingestion of nutrients can lead to postprandial reductions in blood pressure (BP), in older people (even when apparently healthy) [3][4], in part, caused by postprandial diversion of blood to the gut, which can lead to syncope, falls and, in some cases, stroke or death [5][6, 7]. This so-called postprandial hypotension (PPH) has been defined as a fall in systolic blood pressure (SBP) greater than $20 \mathrm{mmHg}$ during the 2 hours following nutrient ingestion i.e it is assumed generally that the maximum fall in SBP occurs within 2 hours. We have recently reported, in a cohort of healthy older men, that ingestion of a $70 \mathrm{~g}$ (280 kcal) whey-protein drink decreased SBP substantially compared to a non-caloric control drink [8]. In the majority of men in that study the SBP decrease was greater than $20 \mathrm{mmHg}$ after the $70 \mathrm{~g}$ whey 
protein drink (11/19 compared to 5/19 after the control drink) [5]. Furthermore, the hypotensive effect of whey protein was prolonged, with a sustained reduction in SBP being evident at 3 hours after the whey protein drink ingestion. It has been suggested that hypertensive men may be of particular risk of blood pressure falls following food intake [13]. The current study aimed to determine the effect of whey protein, replacing some of the whey protein with isocaloric amounts of glucose and fat, and adding carbohydrate and fat to the whey protein, on blood pressure and heart rate responses in older men for 3 hours following the drink. We hypothesized that the hypertensive effects of whey protein containing drinks would often persist for more than 2 hours and be dependent on the energy content of the drink.

\section{Materials And Methods \\ 2.1 Subjects}

Thirteen older men (Mean \pm standard error of mean (SEM)): age: $75 \pm 2$ years; body weight: $79 \pm 2 \mathrm{~kg}$; height: $1.75 \pm 0.01 \mathrm{~m}$; body mass index (BMI): $25.6 \pm 0.6 \mathrm{~kg} / \mathrm{m} 2)$ were recruited by advertisement.

Exclusion criteria were smoking; being vegetarian; alcohol intake of $>2$ standard drinks on $>5$ days per week; use of prescribed or non-prescribed medications which may affect appetite, body weight, gastrointestinal function or energy metabolism ; intake of any illicit substance; known lactose intolerance or food allergy(s); epilepsy; gallbladder, pancreatic, cardiovascular or respiratory diseases; significant gastrointestinal symptoms such as abdominal pain, gastro-esophageal reflux, diarrhea, or constipation or surgery; any other illness deemed significant by the investigator; low levels of plasma ferritin; blood donation in the previous 12 weeks; undernutrition (score < 24 on the Mini Nutritional Assessment [9]); depression (score $\geq 11$ on the Geriatric Depression Questionnaire [10]); impaired cognitive function (score $<25$ on Mini Mental State [11]); or inability to comprehend the study. Anti-hypertensive medication were taken by four older men (; anti-arrhythmic $n=1$; angiotensin-converting enzyme inhibitor, $n=1$; beta blockers, $n=1$; angiotensin receptor blockers $n=1$ ). Participants were instructed to not take medication on the morning of their study visit.

The study was conducted in accordance with the Declaration of Helsinki and Royal Adelaide Hospital Human Research Ethics Committee approved the protocol. The study was registered with the Australian New Zealand Clinical Trial Registry (www.anzctr.org.au, registration number ACTRN12614000846628). All subjects provided written informed consent prior to their study inclusion.

\subsection{Protocol}

Each participant was studied on four occasions in a randomised, double-blind, placebo-controlled design (using randomly permuted blocks; www.randomization.com), separated by 3-14 days, to determine the effects of drinks ( 450 mL) containing either: (i) $70 \mathrm{~g}$ whey protein ( $280 \mathrm{kcal}$; ' $\mathrm{P}_{280}$ '); (ii) $14 \mathrm{~g}$ whey protein, $28 \mathrm{~g}$ carbohydrate, $12.4 \mathrm{~g}$ fat $\left(280 \mathrm{kcal}\right.$; ' $\mathrm{M}_{280}$ '); (iii) $70 \mathrm{~g}$ whey protein, $28 \mathrm{~g}$ carbohydrate, $12.4 \mathrm{~g}$ fat (504 kcal; ' $\mathrm{M}_{504}$ '); or (iv) an iso-palatable control drink ( 2 kcal; 'control') on SBP, DBP and heart rate (HR). The BP and HR data are secondary outcomes of a published study which included results relating 
to energy intake, appetite, gastric emptying and plasma gut hormone concentrations [12]. Sample size and power calculations for the original study were based on the primary outcomes of energy intake and gastric emptying [12].

The drinks were prepared by homogenizing olive oil (Bertolli Australia Pty Ltd., Unilever Australasia, Sydney, NSW, Australia) and dissolving whey protein isolate (Fonterra Co-Operative Group Ltd., Palmerston North, New Zealand) and dextrose, in varying volumes of demineralized water and diet lime cordial (Bickford's Australia Pty Ltd., Salisbury South, SA, Australia), to achieve the desired composition, on the morning of the study day, by a research officer, who was not involved in the data analysis. The drinks were stirred continuously at low speed on a stirring plate to ensure even mixing, were matched for taste and served in a covered cup. Both the investigator and the subject were blinded to the drink condition.

Subjects were provided with a standardized meal [beef lasagne (McCain Foods Pty Ltd, Wendouree, Victoria (VIC), Australia), $\sim 591 \mathrm{kcal}]$ to consume on the night before each study day at $\sim 1900 \mathrm{~h}$. They were instructed to fast overnight $\sim 12$ hours from solids and liquids except water, and to refrain from strenuous physical activity until they attended the laboratory at $\sim 0830 \mathrm{~h}$. The recruitment of participants started in March 2014, and the study was completed in December 2014.

\subsection{Measurements}

On arrival to the clinical research facility lab, level 4 at Adelaide Health and Medical Sciences, The University of Adelaide, Australia, subjects were seated in an upright position where they remained throughout the study. An intravenous cannula was inserted for blood sampling. Subjects sat quietly for 15 minutes then had 3 baseline measures of BP (Dinamap machine) and heart rate at 3-min intervals before drinking the test drink within 2 minutes. BP and HR were measured every 3 minutes until $t=180$ min. $T=0$ min is immediately after the drink.

\subsection{Data and statistical analysis}

Statistical analyses were performed using SPSS software (version 24; IBM, Armonk, NY). Drink-condition effects (control, $\mathrm{P}_{280}, \mathrm{M}_{280}, \mathrm{M}_{504}$ ) were determined by using two-way repeated-measures ANOVA. Significant effects were followed by Bonferroni corrected post-hoc tests to determine which specific drink conditions were different. Statistical significance was accepted at $P<0.05$. All data are presented as means \pm SEMs. Baseline blood pressure represented as $B L$ in the figures was calculated as an average of $-9,-6$ and -3 minute readings. $T=0$ min refers to the point immediately after drink consumption.

\section{Results}

The study protocol was well tolerated by all subjects.

\subsection{Systolic Blood Pressure (SBP)}


Baseline SBP values were not different on the four study days (Mean control: $128 \pm 3 \mathrm{mmHg}, \mathrm{P}_{280}$ : $\left.129 \pm 3 \mathrm{mmHg}, \mathrm{M}_{280}: 130 \pm 5 \mathrm{mmHg}, \mathrm{M}_{504} 127 \pm 4 \mathrm{mmHg}, \mathrm{P}=0.95\right)$.

SBP did not change over the three hours after the control drink. SBP was lower after all three nutrient drinks compared to the control drink, particularly during the second (60-120min $P=0.018)$ and third (120180min $P=0.022$ ) hours, with the greatest reduction after the $M_{504}$ drink $(P=0.008)$ (Figure 1). SBP following $M_{504}$ ingestion was lower when compared to the $P_{28} 0$ drink between $0-60$ min ( $\left.P=0.044\right)$. There was no significant difference between SBP readings after the $P_{280}$ and $M_{280}$ drinks $(P>0.05)$.

Following drink ingestion, a decrease in SBP exceeding $20 \mathrm{mmHg}$ was seen at some time in 3/13 for control, $7 / 13$ for $\mathrm{P}_{280}, 6 / 13$ for $\mathrm{M}_{280}$, and $9 / 13$ for $\mathrm{M}_{504}$. Maximal SBP decreases from baseline (control: $-14 \pm 2 \mathrm{mmHg}, \mathrm{P}_{280}:-22 \pm 2 \mathrm{mmHg}, \mathrm{M}_{280}:-22 \pm 4 \mathrm{mmHg}, \mathrm{M}_{540}-24 \pm 3 \mathrm{mmHg} ; \mathrm{P}=0.11$ ) occurred about two hours after the drinks (time baseline to nadir SBP: control: $99 \pm 16 \mathrm{~min}, \mathrm{P}_{280}: 119 \pm 13 \mathrm{~min}, \mathrm{M}_{280}: 116 \pm 12 \mathrm{~min}, \mathrm{M}_{504}$ : $119 \pm 15 \mathrm{~min} ; \mathrm{P}=0.86$ ) and persisted thereafter following the nutrient drinks (average 120-180min control: $128 \pm 3 \mathrm{mmHg}, \mathrm{P}_{280}: 118 \pm 2 \mathrm{mmHg}, \mathrm{M}_{280}: 120 \pm 4 \mathrm{mmHg}, \mathrm{M}_{504}: 114 \pm 3 \mathrm{mmHg}$ ).

\subsection{Diastolic Blood Pressure (DBP)}

Baseline DBP values were not different on the four study days (Mean control: $74 \pm 2 \mathrm{mmHg}, \mathrm{P}_{280}$ : $74 \pm 2 \mathrm{mmHg}, \mathrm{M}_{280}: 75 \pm 3 \mathrm{mmHg}, \mathrm{M}_{504} 73 \pm 2 \mathrm{mmHg}, \mathrm{P}=0.94$ ). DBP was lower after all three nutrient drinks compared to the control drink, with the greatest reduction after $\mathrm{M}_{504}$ (Figure 2).

DBP did not change over the three hours after the control drink. DBP was less after $M_{504}(P<0.001)$ and $P_{280}(P=0.026)$ when compared to control - the drink-condition effect was significant during all three hours following drink ingestion ( $0-60$ min $P=0.002,60-120 \mathrm{~min} P=0.004,120-180 \mathrm{~min} P=0.003)$. There was no difference between the effects of $\mathrm{M}_{280}$ and $\mathrm{P}_{280}$ on DBP $(\mathrm{P}>0.05)$.

Maximal DBP decreases from baseline (control: $-12 \pm 2 \mathrm{mmHg}, \mathrm{P}_{280}:-15 \pm 1 \mathrm{mmHg}, \mathrm{M}_{280}:-15 \pm 2 \mathrm{mmHg}$, $M_{504}:-15 \pm 1 \mathrm{mmHg}, \mathrm{P}=0.17$ ) occurred on average between one to two hours after drink ingestion (time baseline to nadir: control: $\left.80 \pm 17 \mathrm{~min}, \mathrm{P}_{280}: 108 \pm 16 \mathrm{~min}, \mathrm{M}_{280}: 71 \pm 12 \mathrm{~min}, \mathrm{M}_{504}: 99 \pm 15 \mathrm{~min}, \mathrm{P}=0.24\right)$ and persisted during the third hour for $\mathrm{P}_{280}$ and $\mathrm{M}_{504}$ (average control: $74 \pm 1 \mathrm{mmHg}, \mathrm{P}_{280}: 68 \pm 1 \mathrm{mmHg}, \mathrm{M}_{280}$ : $71 \pm 1 \mathrm{mmHg}, \mathrm{M}_{504}: 66 \pm 1 \mathrm{mmHg}$ ).

\subsection{Heart Rate (HR)}

Baseline HR values were not different on the four study days (Mean control: $58 \pm 2 \mathrm{bpm}, \mathrm{P}_{280}: 59 \pm 3 \mathrm{bpm}$, $\mathrm{M}_{280}$ : 59 $\pm 2 \mathrm{bpm}, \mathrm{M}_{504} 59 \pm 3 \mathrm{bpm}, \mathrm{P}=0.95$ ).

HR decreased over 3 hours after the control drink and increased after the $M_{504}(P<0.001)$ when compared to control, and did not change significantly after either the $\mathrm{M}_{280}$ or $\mathrm{P}_{280}$ drinks (0-180min average control: $57 \pm 1 \mathrm{bpm}, \mathrm{P}_{280}: 60 \pm 1 \mathrm{bpm}, \mathrm{M}_{280}: 60 \pm 2 \mathrm{bpm}, \mathrm{M}_{504}: 63 \pm 1 \mathrm{bpm}$; Figure 3). The drink-condition effect was 
significant during all the three hours $(0-60$ min $P=0.001,60-120$ min $P<0.001,120-180$ min $P<0.001)$ hour following drink ingestion.

Maximal HR increase from baseline (control: $3.8 \pm 1 \mathrm{bpm}, \mathrm{P}_{280}: 9 \pm 2 \mathrm{bpm}, \mathrm{M}_{280}: 12 \pm 4 \mathrm{bpm}, \mathrm{M}_{504} 13 \pm 2 \mathrm{bpm}$, $P<0.001$.) occurred on average between one to two hours after drink ingestion (time baseline to peak: control: $48 \pm 14 \mathrm{~min}, \mathrm{P}_{280}: 116 \pm 15 \mathrm{~min}, \mathrm{M}_{280}: 83 \pm 14 \mathrm{~min}, \mathrm{M}_{504}: 127 \pm 16 \mathrm{~min}, \mathrm{P}=0.003$ ) and persisted during the third hour for $P_{280}$ and $M_{504}$ (average control: $55 \pm 1 b p m, P_{280}: 61 \pm 1 b p m, M_{280}: 60 \pm 1 b p m$, $\left.\mathrm{M}_{504}: 64 \pm 1 \mathrm{bpm}\right)$.

\section{Discussion}

The major observation in this study is that in healthy older men following ingestion of nutrient drinks containing 280 or $504 \mathrm{kcal}$ energy as pure whey protein or as mixed macronutrients, the magnitude of the decrease in BP is dependent on the energy content, rather than, the macronutrient composition of the drinks; greater decreases occurred after the $504 \mathrm{kcal}$ than both $280 \mathrm{kcal}$ drinks, with no difference between their effects on BP. Furthermore, while the onset of the BP reduction was soon after nutrient drink ingestion, particularly after the $504 \mathrm{kcal}$ drink, the hypotensive effect was sustained for at least 3 hours the time at which our observations ceased. Both observations are of potential clinical importance.

In contrast to the effect of energy load, the extent of BP decrease after the nutrient drinks was not dependent on the macronutrient composition of the drinks with the effects of $280 \mathrm{kcal}$ ingested as pure whey protein not differing from those of $280 \mathrm{kcal}$ ingested as $14 \mathrm{~g}$ whey protein, $28 \mathrm{~g}$ carbohydrate and

$12.4 \mathrm{~g}$ fat. The $\mathrm{M}_{504}$ drink was associated with the greatest BP decreases and HR increases of any of the drinks.

Heart rate increased after ingestion of the nutrient drinks compared to the control drink, with the greatest and more sustained increase after the highest energy load drink. The resultant increase in cardiac output acts as a mechanism to compensate for the potential postprandial fall in BP caused by postprandial diversion of blood to the gut. The nutrient-induced increases in HR were not adequate, however, to compensate fully for this diversion in these older men. We have previously found smaller increases in HR and larger decreases in BP in healthy older than younger men after a pure $70 \mathrm{~g}$ whey protein drink [8]. This suggests that an age-related reduction in the ability to increase the heart rate after food ingestion contributes to the greater reduction in BP observed in older than younger adults after nutrient ingestion.

The nutrient drink-induced decreases in BP were substantial- a decrease of $20 \mathrm{mmHg}$ SBP or more occurred at some time after the nutrient drinks on $59 \%$ of study days, including $77 \%$ of the $504-\mathrm{kcal}$ drink days, compared to $31 \%$ of the control drink days. None of the men in this study reported symptoms of dizziness or faintness, but they were seated throughout the study and not permitted to get up and walk around. A systolic BP drop of $20 \mathrm{mmHg}$ or more is clearly e associated with symptoms and an increased likelihood of falls and injury, as reflected in one recommended definition of postprandial hypotension [5]. Caution should, therefore, possibly be exercised for several hours (certainly more than two) at least by 
older people mobilising after nutrient containing drinks, particularly if they also experience postural hypotension and if substantial nutrient loads are ingested. Patients may, therefore benefit from more frequent, lower calorie drinks or meals, and further studies should examine this strategy, including dose response studies (15).

Limitations of this study include that it was only conducted in men. While women tend to have a lower baseline BP that would intuitively predispose them lower BP levels after a meal, we and others have shown that the magnitude of the postprandial fall in BP is directly related to baseline BP such that the fall is greater in those who are hypertensive $[13,14]$ Further limitations include that the participants were sitting for the entire study day, to standardize study conditions and the number of participants was relatively small. Nevertheless, the observed decreases in BP and HR were clear cut. Because, the effects of the drinks on BP were still evident at 3 hours, when each study ceased, it would be useful to know the total duration of the postprandial hypotension effects.

Our observations suggest that if the intention is to give an older person a nutritional supplement drink containing as much whey protein as possible to preserve, or even enhance, muscle mass and function, then administering it in as pure a form as possible (i.e., with the minimum amount of fat and carbohydrate) will lower the BP the least and so be associated with a lower risk of postprandial hypotension - i.e. the isocaloric $(280 \mathrm{kcal}) 70 \mathrm{~g}$ pure whey protein drink did not lower BP more than the $14 \mathrm{~g}$ whey protein mixed macronutrient drink. If, on the other hand, the intention is to provide a mixed macronutrient supplement to provide a certain amount of energy, it should be appreciated the total energy content of the supplement, rather than its macronutrient composition will be the major determinant of its BP effect.

\section{Conclusions}

Consumption of mixed macronutrient drinks may reduce BP for at least 3 hours and the effect is dependent on overall energy intake rather than the macronutrient composition of the drink. Pure whey protein drinks may accordingly represent the best approach to maximise protein intake while minimising the potential for deleterious BP falls in older people.

\section{List Of Abbreviations}

BMI, body mass index; SEM, standard error of mean; SBP, systolic blood pressure; DBP, diastolic blood pressure; $\mathrm{HR}$, heart rate

\section{Declarations}

Ethics approval and consent to participate: The study was conducted according to the guidelines of the Declaration of Helsinki, and approved by the Royal Adelaide Hospital Human Research Ethics Committee. The study was registered with the Australian New Zealand Clinical Trial Registry (www.anzctr.org.au, 
registration number ACTRN12614000846628, date of registration 14/03/2019). Written informed consent was obtained from all subjects involved in the study. All methods were performed in accordance with the relevant guidelines and regulations.

Consent for publication: Not applicable

Availability of data and materials:

The datasets generated and/or analyzed during the current study are not publicly available due to ethical restrictions of the protocol having mentioned in our approved local ethical application that data will not be available for the general public but are available from the corresponding author on reasonable request.

Competing Interests: The authors declare no conflict of interest. Fonterra and the Royal Adelaide Hospital Research Fund had no role in the design of the study; in the collection, analyses, or interpretation of data; in the writing of the manuscript, or in the decision to publish the results.

Funding: The research was funded by a Royal Adelaide Hospital Clinical Project Grant (\#1753). Stijn Soenen was supported by a Royal Adelaide Hospital Florey Fellowship (\#2129).

Author Contributions: CG, MH, KJ, IC and SS designed the research. CG and SS conducted the research. CG generated the random allocation sequence, and enrolled and assigned the participants to the interventions. $\mathrm{AO}, \mathrm{KL}, \mathrm{IC}$ and SS performed the statistical analyses. $\mathrm{AO}, \mathrm{KL}, \mathrm{KJ}, \mathrm{MH}, \mathrm{IC}$ and SS contributed to data interpretation. $\mathrm{AO}, \mathrm{CG}, \mathrm{KL}, \mathrm{KJ}, \mathrm{MH}, \mathrm{IC}$ and $\mathrm{SS}$ contributed to writing the manuscript and $\mathrm{SS}$ had primary responsibility for the final content.

Acknowledgments: We thank Fonterra Research and Development Centre, Palmerston North, New Zealand, for providing the whey protein (isolated whey protein, description \#104641), and Rachael Rigda and Seva Hatzinikolas, Centre of Research Excellence in Translating Nutritional Research to Good Health, Discipline of Medicine, Royal Adelaide Hospital, the University of Adelaide for assistance during the study days. Karen Jones' salary was supported by a University of Adelaide William T Sothcott Research Fellowship.

Author details: ${ }^{1}$ Adelaide Medical School and Centre of Research Excellence in Translating Nutritional Science to Good Health, The University of Adelaide, Adelaide, Royal Adelaide Hospital, South-Australia, Australia

2 Riddett Institute, Massey University, Palmerston North 9430, New Zealand

${ }^{3}$ Faculty of Health Sciences and Medicine, Bond University, Robina, QLD 4226, Australia

\section{References}


1. Bauer J, Biolo G, Cederholm T, Cesari M, Cruz-Jentoft AJ, Morley JE, et al. Evidence-based recommendations for optimal dietary protein intake in older people: a position paper from the PROTAGE Study Group. J Am Med Dir Assoc. 2013; 14(8): 542-59.

2. Pennings B, Boirie Y, Senden JMG, Gijsen AP, Kuipers H, Loon LJCV. Whey protein stimulates postprandial muscle protein accretion more effectively than do casein and casein hydrolysate in older men. Am J Clin Nutr. 2011; 93(5): 997-1005.

3. Trahair LG, Vanis L, Gentilcore D, Lange K, Rayner CK., Horowitz, M, et al. Effects of variations in duodenal glucose load on blood pressure, heart rate, superior mesenteric artery blood flow and plasma noradrenaline in healthy young and older subjects. Clin Sci (Lond). 2012; 122(6): 271-9.

4. Jones KL, Tonkin A, Horowitz M, Wishart JM, Carney Bl, Guha S, et al. Rate of gastric emptying is a determinant of postprandial hypotension in non-insulin-dependent diabetes mellitus. Clin Sci (Lond). 1998; 94(1): 65-70.

5. Jansen RW, Lipsitz L.A. Postprandial hypotension: epidemiology, pathophysiology, and clinical management. Ann Intern Med. 1995; 122(4): 286-95.

6. National Institute on Aging, N.I.o.H., Global Health and Aging. NIH Publication no. 117737.Washington, DC: World Health Organization, 2011.

7. Vasan RS, Beiser, A, Seshadri S, Larson MG, Kannel WB, D'Agostino RB, et al. Residual lifetime risk for developing hypertension in middle-aged women and men: The Framingham Heart Study. JAMA. 2002; 287(8):1003-1010.

8. Giezenaar C, Oberoi A, Jones KL, Horowitz M, Chapman I, Soenen S. Effects of age on blood pressure and heart rate responses to whey protein in younger and older men. J Am Geriatr Soc. 2021; 69(5): 1291-1299.

9. Guigoz Y, Vellas B, Garry PJ. Assessing the nutritional status of the elderly: The Mini Nutritional Assessment as part of the geriatric evaluation. Nutr Rev. 1996; 54(1 Pt 2): S59-65.

10. Yesavage JA, Brink TL, Rose TL, Lum O, Huang V, Adey M, et al. Development and validation of a geriatric depression screening scale: a preliminary report. J Psychiatr Res. 1982; 17(1): 37-49.

11. Folstein MF, Folstein SE, McHugh PR. "Mini-mental state". A practical method for grading the cognitive state of patients for the clinician. J Psychiatr Res. 1975; 12(3): 189-98.

12. Giezenaar C, Burgh YVD, Lange K, Hatzinikolas S, Hausken T, Jones KL, et al. Effects of Substitution, and Adding of Carbohydrate and Fat to Whey-Protein on Energy Intake, Appetite, Gastric Emptying, Glucose, Insulin, Ghrelin, CCK and GLP-1 in Healthy Older Men-A Randomized Controlled Trial. Nutrients. 2018; 10(2): 113.

13. Madden KM, Feldman B, Meneilly GS. Characteristics Associated with the Postprandial Hypotensive Response in Falling Older Adults. Can J Aging. 2019; 38(4): 434-440.

14. Pham H, Phillips L, Trahair L, Hatzinikolas S, Horowitz M, Jones KL. Longitudinal Changes in the Blood Pressure Responses to, and Gastric Emptying of, an Oral Glucose Load in Healthy Older Subjects. J Gerontol A Biol Sci Med Sci. 2020; 75(2): 244-248. 
15. Puvi-Rajasingham S, Mathias, CJ. Effect of meal size on post-prandial blood pressure and on postural hypotension in primary autonomic failure. Clin Auton Res. 1996; 6(2): 111-4.

\section{Figures}

\section{Systolic Blood Pressure}

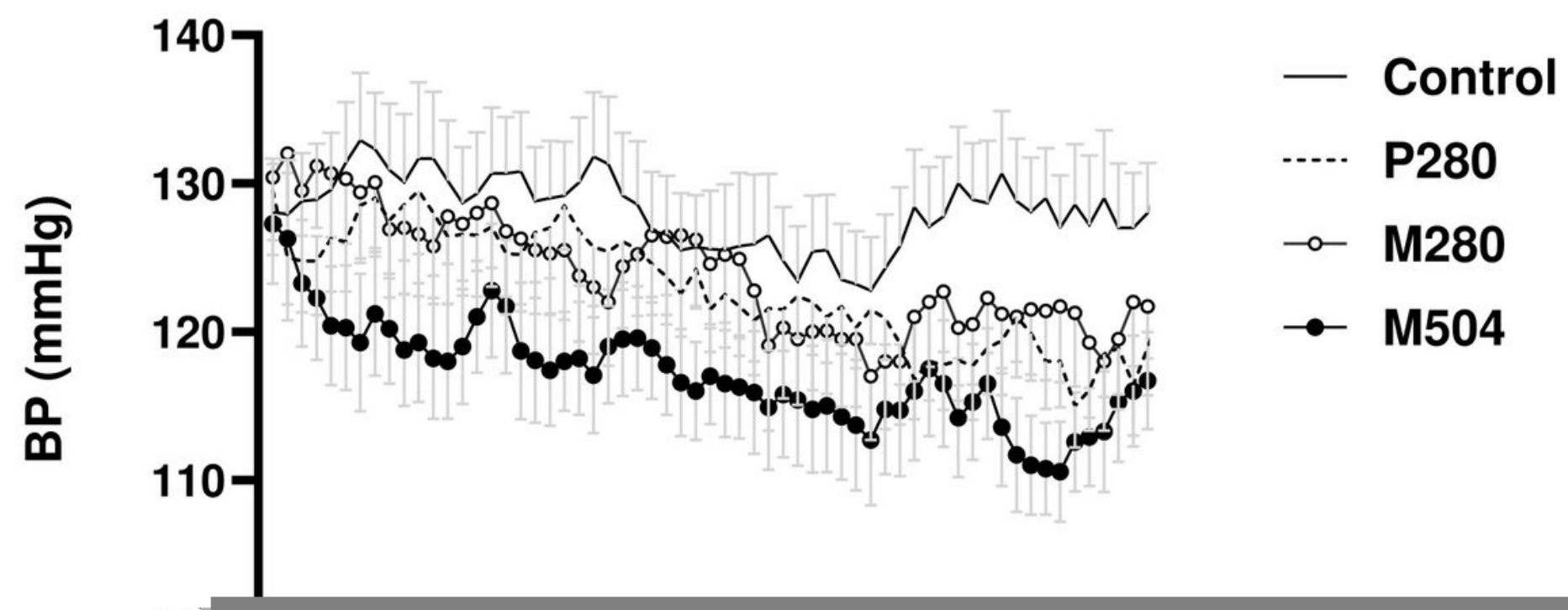

Figure 1

Mean ( \pm SEM) systolic blood pressure (SBP; $\mathrm{mmHg}$ ) following drink ingestion containing (i) flavored water (control, $\sim 2 \mathrm{kcal}$ ) or (ii) $70 \mathrm{~g}$ whey protein ( $280 \mathrm{kcal}$; ' $\mathrm{P}_{280}$ '); (iii) $14 \mathrm{~g}$ whey protein, $28 \mathrm{~g}$ carbohydrate, $12.4 \mathrm{~g}$ fat (280 kcal; 'M280'); (iv) $70 \mathrm{~g}$ protein, $28 \mathrm{~g}$ carbohydrate, $12.4 \mathrm{~g}$ fat (504 kcal; ' $M_{504}$ ') in older ( $\left.n=13\right)$ men. Drink-condition effects were determined by using repeated-measures ANOVA. Baseline blood pressure represented as $B L$ in the figure was calculated as an average of $-9,-6$ and -3 minute readings. $T=0$ min refers to the point immediately after drink consumption. SBP was lower after the $\mathrm{M}_{504}$ drink when compared to control $(P=0.019)$ during the second $(60-120 \mathrm{~min} P=0.035)$ and third (120-180min $\mathrm{P}=0.005)$ hour. 


\section{Diastolic Blood Pressure}

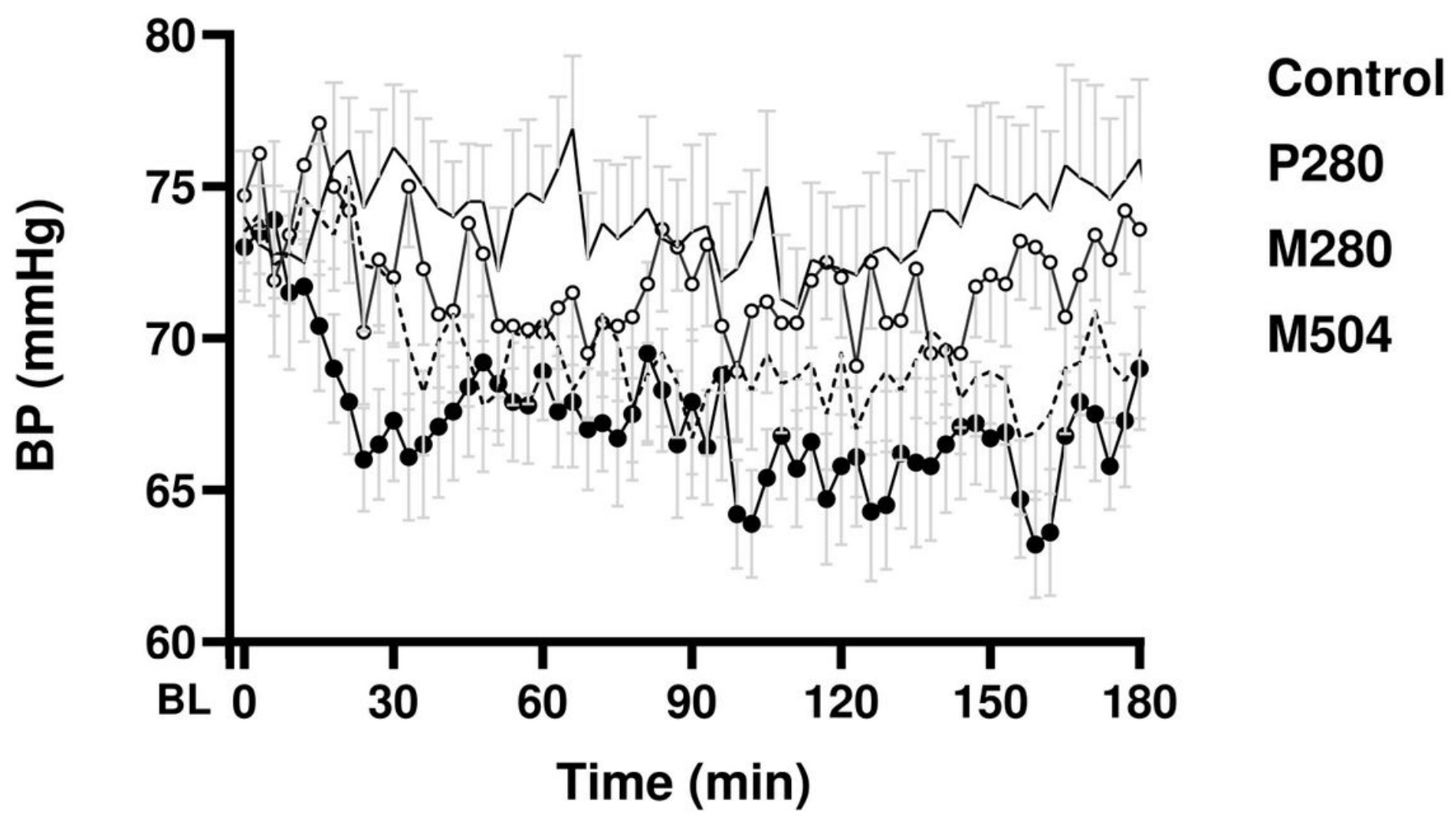

Figure 2

Mean ( \pm SEM) systolic blood pressure (DBP; $\mathrm{mmHg}$ ) following drink ingestion containing (i) flavored water (control, $\sim 2 \mathrm{kcal}$ ) or (ii) $70 \mathrm{~g}$ whey protein ( $280 \mathrm{kcal}$; ' $\mathrm{P}_{280}$ '); (iii) $14 \mathrm{~g}$ whey protein, $28 \mathrm{~g}$ carbohydrate, $12.4 \mathrm{~g}$ fat ( $280 \mathrm{kcal}$; ' $\mathrm{M}_{280}$ '); (iv) $70 \mathrm{~g}$ protein, $28 \mathrm{~g}$ carbohydrate, $12.4 \mathrm{~g}$ fat ( $504 \mathrm{kcal}$; ' $\mathrm{M}_{504}$ ') in older $(n=13)$ men. Drink-condition effects were determined by using repeated-measures ANOVA. Baseline blood pressure represented as $B L$ in the figure was calculated as an average of $-9,-6$ and -3 minute readings. $T=0$ min refers to the point immediately after drink consumption. DBP was lower after the $M_{504}(P<0.001)$ and $P_{280}(P=0.018)$ drinks when compared to control during the second $(P=0.012)$ and third $(P=0.035)$ hour. There was no statistically significant difference between the effects of $M_{280}$ and $\mathrm{P}_{28} \mathrm{O}$ on $\mathrm{BP}$. 


\section{Heart Rate}

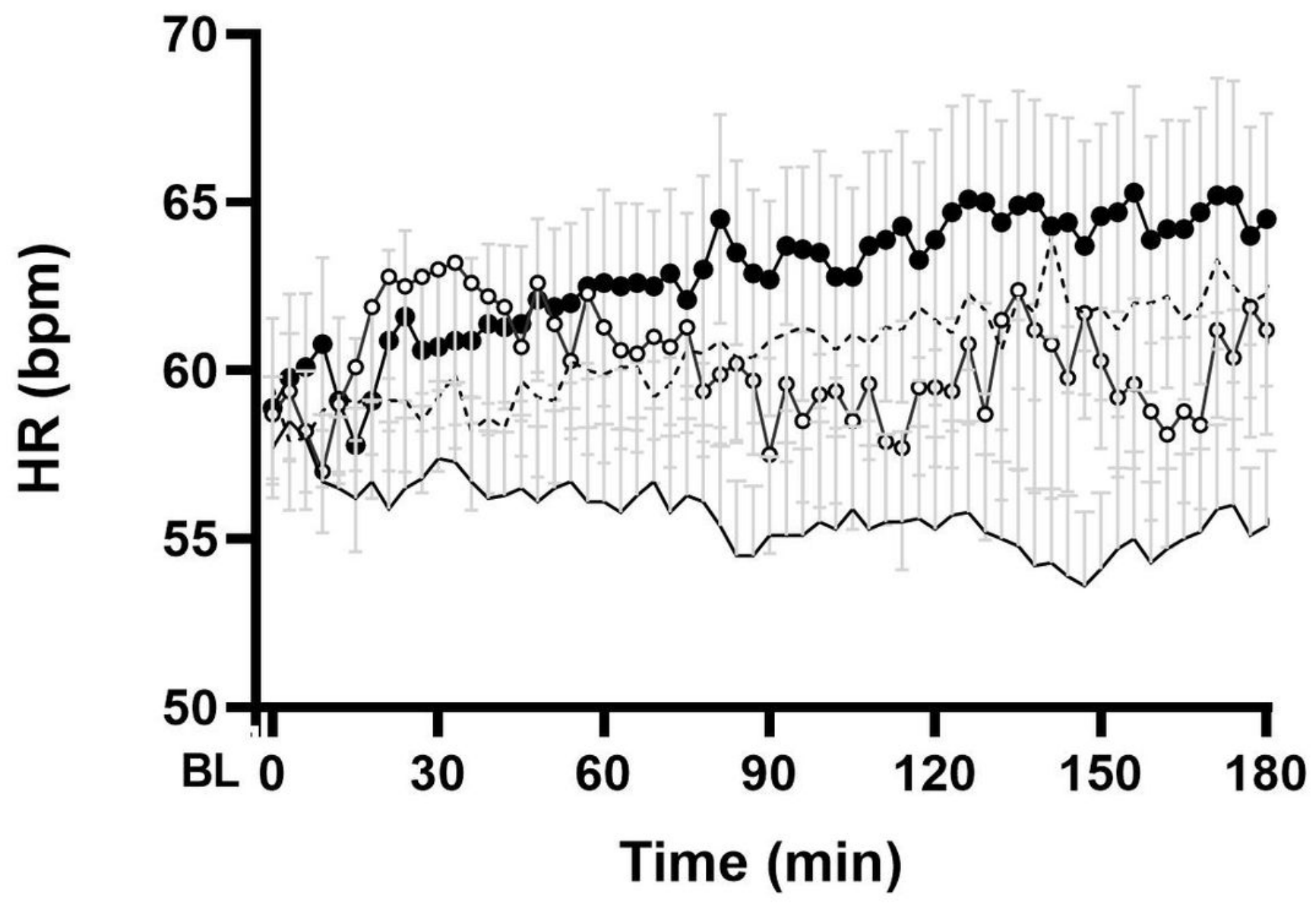

Figure 3

Mean ( \pm SEM) Heart Rate (HR; bpm) following drink ingestion containing (i) flavored water (control, $\sim 2 \mathrm{kcal}$ ) or (ii) $70 \mathrm{~g}$ whey protein $\left(280 \mathrm{kcal} ;{ }^{2} \mathrm{P}_{280}\right.$ '); (iii) $14 \mathrm{~g}$ whey protein, $28 \mathrm{~g}$ carbohydrate, $12.4 \mathrm{~g}$ fat (280 kcal; ' $M_{280}$ '); (iv) $70 \mathrm{~g}$ protein, $28 \mathrm{~g}$ carbohydrate, $12.4 \mathrm{~g}$ fat $\left(504 \mathrm{kcal}\right.$; ' $\mathrm{M}_{504}$ ') in older ( $\left.\mathrm{n}=13\right)$ men. Drink-condition effects were determined by using repeated-measures ANOVA. Baseline Heart rate represented as $B L$ in the figure was calculated as an average of $-9,-6$ and -3 minute readings. $T=0$ min refers to the point immediately after drink consumption. $H R$ increased after the $M_{504}(P<0.001)$ and $P_{280}$ $(P=0.017)$ drinks when compared to control (0-180min). 